\title{
Distribution of smaller benthic foraminifera in the Chagos Archipelago, Indian Ocean
}

\author{
JOHN W. MURRAY ${ }^{1}$ \& CHRISTOPHER W. SMART ${ }^{2}$ \\ 'Department of Geology, University of Southampton, Southampton SO17 1BJ, UK. \\ 'Department of Geology, University of Wales College of Cardiff, PO Box 914, Cardiff CF1 3YE. UK.
}

\begin{abstract}
The Chagos Archipelago is a series of atolls situated in the centre of the Indian Ocean close to the equator. The area experiences small tides and periods of strong winds. The combined effects of these is to cause relatively high energy conditions to exist in the shallow waters around the reefs, therefore the bottom sediments are coarse grained and mobile. Although the coral faunas are diverse, seagrasses are rare. The total benthic foraminiferal assemblages have low to high species diversity and are dominated by hyaline taxa. On the oceanic side of the atoll reefs, the dominant foraminiferan is Amphistegina lessonii, with subsidiary miliolids. Planktonic tests form up to $20 \%$ of the combined benthic and planktonic component. In the lagoon, the assemblages ase dominated by Calcarina calcar, with subsidiary miliolids. Planktonic tests are relatively uncommon. Some postmortem transport and damage to tests has taken place but the distribution patterns are believed to be representative of the original living ones. J. Micropalaeontol. 13(1): 47-53, September 1994.
\end{abstract}

\section{INTRODUCTION}

The Chagos Archipelago is the most remote Indian Ocean atoll (Fig. 1). It is situated within the gyre formed by the westward-flowing Equatorial Current to the south and the eastward-flowing Indian Counter Current to the north which effectively isolates it from the Maldive Islands. Because of its geographic isolation it is of particular biogeographic interest. The samples discussed here come from Peros Banhos atoll. The larger foraminifera are discussed in Murray (in press) who showed that the fauna is less diverse than that of the Mauritius and Comoro island groups.

The only previous study of smaller benthic foraminifera from an Indian Ocean atoll is that of Hottinger (1980) on the Maldive Islands and there have been few studies of oceanic island faunas: Comoro Islands (LeCalvez in Guilcher et al., 1965), îles Glorieuses (Battistini et al., 1976), Kerimba archipelago (Heron-Allen \& Earland, 1914-1915), Mascarenc Islands (Montaggioni, 1981). Murray (1991) summarized the distribution of smaller foraminifera from the Indian Ocean in general.

\section{THE ENVIRONMENT}

The Chagos bank is part of a lineament (Chagos-Laceadive Ridge) formed by volcanic activity along a north-south transform fault during the Teriary opening of the Indian Ocean (McKenzie \& Sclater, 1971). On leg 115 of ODP, Site 71.3 was drilled on the northern edge of the bank. Forty-two metres of basalts were drilled and these give a weighted mean plateau age of $49.0 \pm 1.0 \mathrm{Ma}$ and a weighted mean isochron age of $49.6 \pm 0.6 \mathrm{Ma}$ (Duncan \& Hargreaves, 1990). Interbedded baked sediments were assigned to calcareous nannofossil Subzone CP13b, early to middle Eocene, and were deposited in moderate water depths. The present depth of Site 713 is $2915 \mathrm{~m}$ (Backman, Duncan et al., 1988).

The Chagos Archipelago is the surface expression of a thin limestone cap resting on the volcanic basement. During the Pleistocene lowstand of sea level, the area of land exposed was about $13000 \mathrm{~km}^{2}$ greater than now. Peros Banhos atoll lies to the north of the major Great Chagos Bank. The coral recfs are the largest area of undisturbed reefs in the Indian Ocean. The coral and mollusc faunas are diverse but this is not the case for fish or algae (Sheppard \& Wells 1988). On the oceanward side, the reefs have a groove and spur structure extending down to $5 \mathrm{~m}$ but this dies out in the channels as the reefs pass into the lagoon (Sheppard, 1981).

Peros Banhos atoll is centred on $5^{\circ} 20^{\prime} \mathrm{S}, 71^{\circ} 50^{\prime} \mathrm{E}$ (Fig. 1). It has an area of $463 \mathrm{~km}^{2}$, a maximum lagoon depth of $80 \mathrm{~m}$ and an average of $38 \mathrm{~m}$. The atoll is rather square in shape and the channels between the numerous islands allow good exchange of water between the open sea and the lagoon. The total length of reef is $94.5 \mathrm{~km}$ and the total width of channels $30.5 \mathrm{~km}$. The tidal range is normally $<1 \mathrm{~m}$. The waters are well oxygenated and have a temperature range of $25-30^{\circ} \mathrm{C}$; the lagoon surface waters commonly exceed those of the open ocean by $>2^{\circ} \mathrm{C}$ (Pugh \& Rayner, 1981). Primary productivity off île du Coin is $15.7 \mu \mathrm{g} \mathrm{Cl}^{\prime} \mathrm{h}$ ' oceanwards and $11.8 \mu \mathrm{g} \mathrm{Cl} \mathrm{C}^{\prime} \mathrm{h}$ in the lagoon (Rayner \& Drew 1984). On the outer reef slopes, the water has high clarity but this is reduced to around $30 \mathrm{~m}$ in the lagoon. South East Trade Winds blow strongly from May to September while from October to April there arc light to moderate northwesterly winds. Severe storms are rare but even during calm weather there is a marked swell. Rainfall is $4000 \mathrm{~mm}$ per annum (Sheppard, 1981: Sheppard \& Wells, 1988).

The sediment is exclusively biogenic and calcareous being composed mainly of coral and algal bioclasts. Only in a few decper lagoonal samples from off Petite île Coquillage is there any size fraction $<63 \mu \mathrm{m}$. From visual examination. 


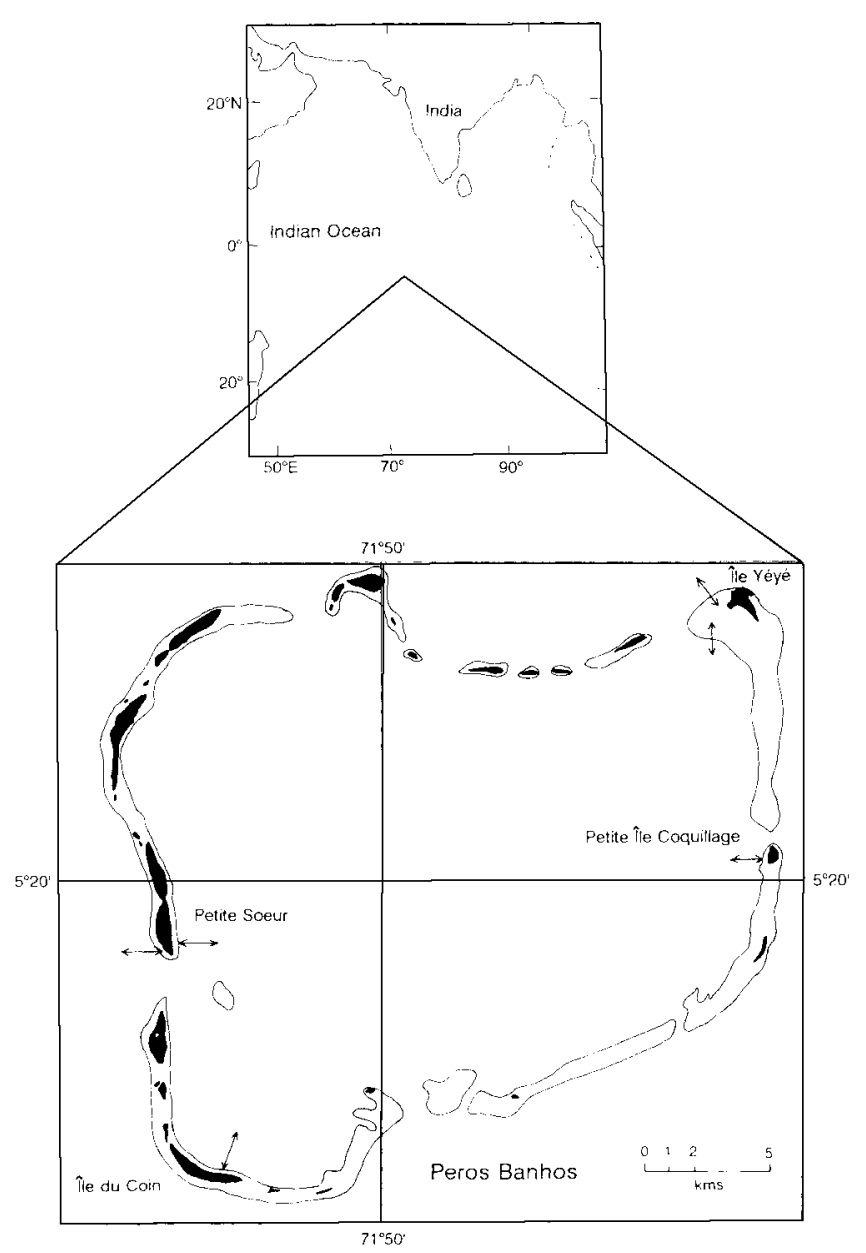

Fig. 1. Map of Peros Banhos atoll, Chagos Archipelago, Indian Ocean. Arrows indicate traverses studied.

most sediments are composed of fine, medium, coarse and very coarse sand with granule-sized gravel.

Sheppard (1980) used phototransects, particularly in the lagoon off île du Coin, to determine the proportions of bottom cover; from $3-30 \mathrm{~m}$, 'sand, i.e. loose sediment, covers $15-35 \%$, bare hard surfaces $15-20 \%$, coral and soft coral $50-70 \%$. He noted that '...much bare rock exists for no obvious reason' although heavy wave action and shifting sediment were mentioned as possible explanations. Drew (1980) observed that large areas of potentially suitable habitat for seagrasses remained uncolonized, perhaps due to 'geographical isolation, lack of appropriate substrates and an excessive exposure to wind and waves'. The virtual absence of seagrass has profound implications for availability of suitable substrates for phytal foraminifera. However, fragments of Halimeda are widespread, commonly abundant and may serve as substrates for some foraminifera.

\section{MATERIAL AND METHODS}

The samples were collected from Peros Banhos by the late Dr Paul Morris in April-May 1979 on the Joint Services
Chagos Research Expedition. Sampling was carried out by SCUBA diving and was generally limited to depths $\leq 43 \mathrm{~m}$. Material was preferentially collected from bare sediment surfaces. Each of the 47 samples had a volume of $85 \mathrm{~cm}^{3}$ and was preserved in formalin or alcohol. In most cases the preservative had dried out but, nevertheless, a few tests had observable cytoplasm coloured by the symbionts. Seven samples were processed with rose Bengal but yielded few red stained individuals. It was decided not to stain the bulk of the samples because of the uncertainty of preservation. In addition, since bare sediment was collected, it was considered unlikely that the living habitat of most of the foraminifera had been sampled. Thus, the assemblages described here are total, i.e., living plus dead.

In the laboratory, the samples were washed over a $63 \mu \mathrm{m}$ sieve and dried. They were then dry sieved on a $1.4 \mathrm{~mm}$ sieve to remove the coarse fraction which was studied separately for larger foraminifera (Murray, in press). The foraminifera were picked from the $63 \mu \mathrm{m}-1.4 \mathrm{~mm}$ size fraction and mounted on slides. At least 250 benthic individuals were picked to give the total benthic assemblage. Species diversity has been expressed as the alpha index of Fisher et al. (1943). In addition, the planktonic:benthic ratio was determined and expressed as percentage planktonic of benthic plus planktonic.

No attempt has been made to identify all the benthic taxa because most are rare. A partial faunal reference list is given in Appendix 1 and most taxa are illustrated in Fig. 6.

\section{RESULTS}

The results are presented as traverses from the reef barrier both into the lagoon and seawards into the open ocean (Figs 1-5). Although there are similarities in the assemblages, there are also some major differences. Species diversity in the lagoon ranges from $\alpha \quad 2-21$ (average 12), with exceptional values of $\alpha 27-33$ on very fine sediment, to $\alpha$ 8-21 (average 14) in the open sea. The assemblages have high faunal dominance with the most abundant species usually making up $>30 \%$ and commonly $>50 \%$ of the total. In terms of wall structure, hyaline ranges from $61-96 \%$, porcellaneous from $4-30 \%$ and agglutinated from $0-13 \%$. All the agglutinated taxa have a calcareous cement and all the detrital particles are calcareous (and biogenic) because there are no non-carbonate rocks exposed on the atoll.

The seaward profiles off Yéyć and Petite Soeur (Figs 2,3) are dominated by Amphistegina lessonii (25-56\%), with modest numbers of miliolids (0-21\%) and Calcarina calcar $(1-20 \%)$. No other taxa are present in $>10 \%$ abundance except for Heterostegina depressa in the shallowest samples off Petite Soeur. The abundance of planktonic tests ranges from 2 to $20 \%$ and shows a general seaward increase.

The four lagoon profiles are from Yéyé, Petite Soeur, île du Coin and Petite île Coquillage (Figs 2-5). Calcarina calcar is the dominant species: $65-90 \%$ off Petite Soeur, $12-84 \%$ off Yéyé and île du Coin. The only other abundant group is the miliolids but these are very variable $(<1-30 \%)$. Amphistegina lessonii is $<5 \%$ off YéYé and Petite Soeur, but off île du Coin it ranges from 1-20\%. Off Petite île 

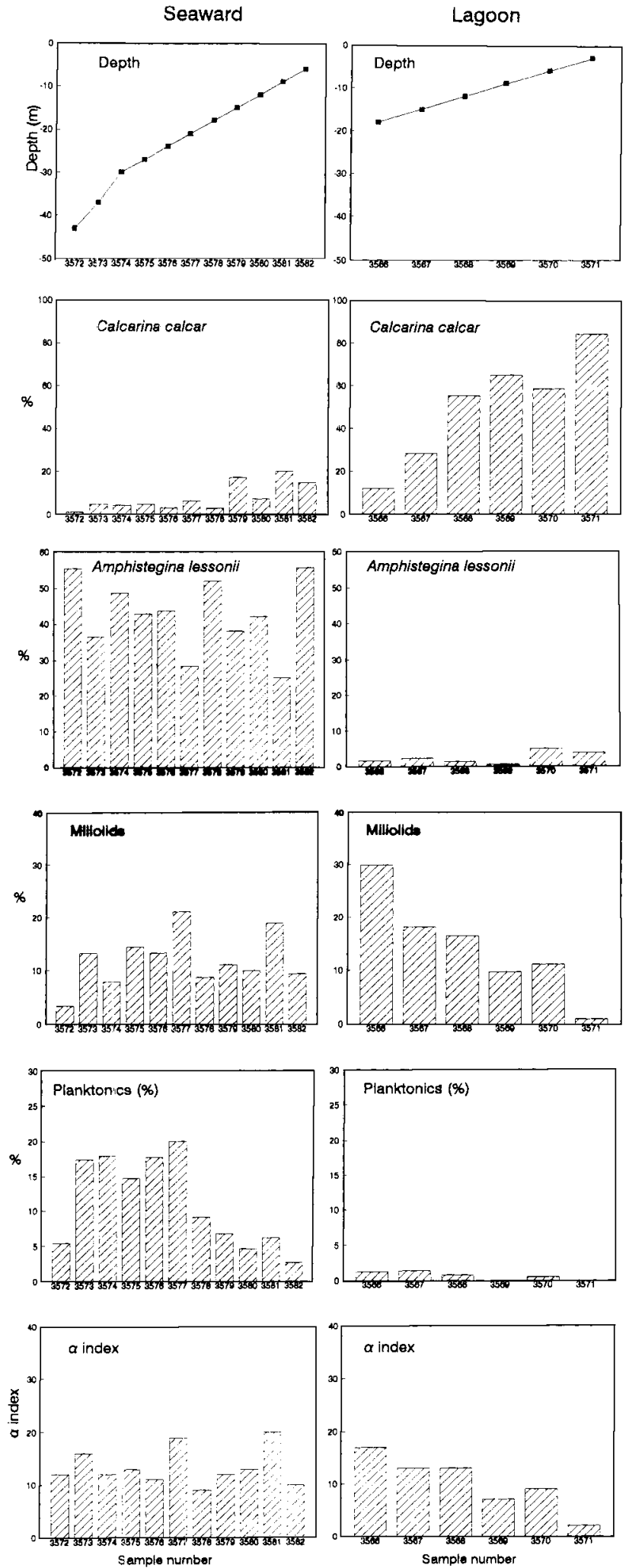

Fig. 2. Frequency distribution of Calcarina calcar, Amphistegina lessonii, miliolids, $\alpha$ index and $\%$ planktonic foraminifera in depth traverses off île Yéyé.
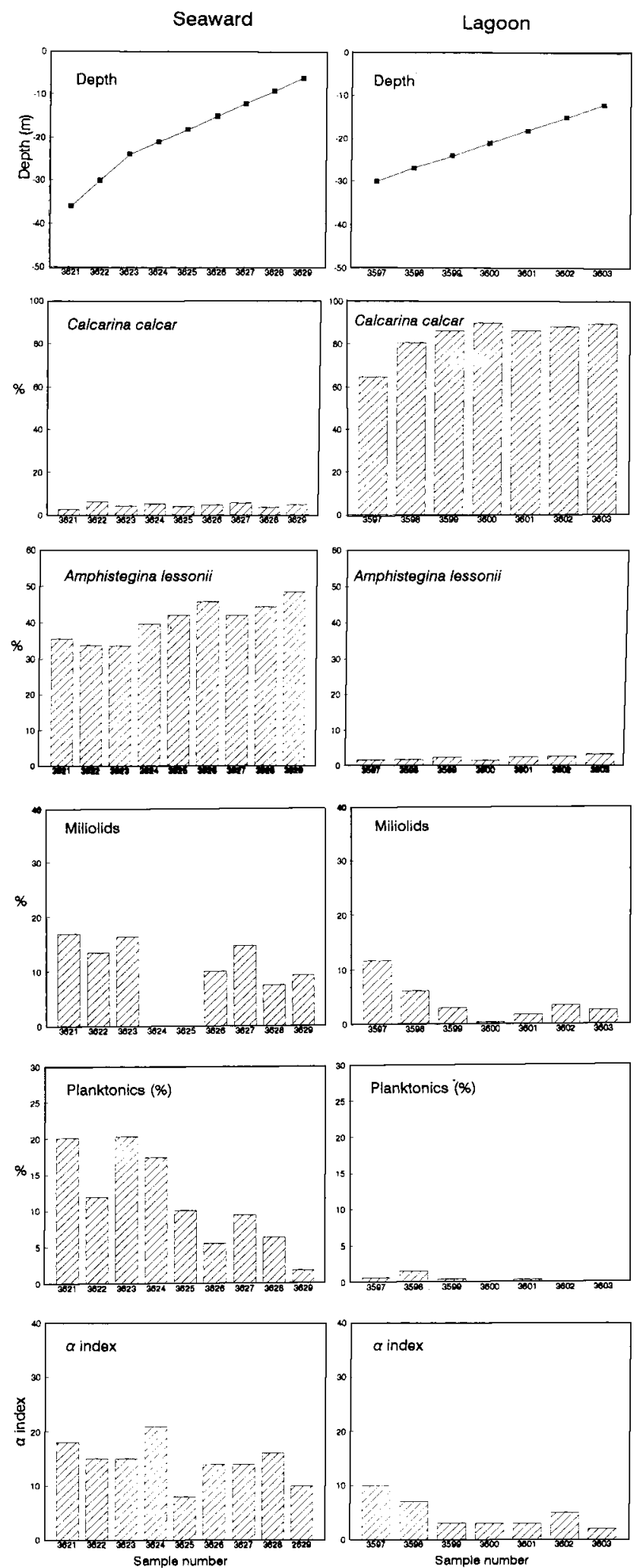

Fig. 3. Frequency distribution of Calcarina calcar, Amphistegina lessonii, miliolids, $\alpha$ index and \% planktonic foraminifera in depth traverses off Petite Soeur. 
Lagoon
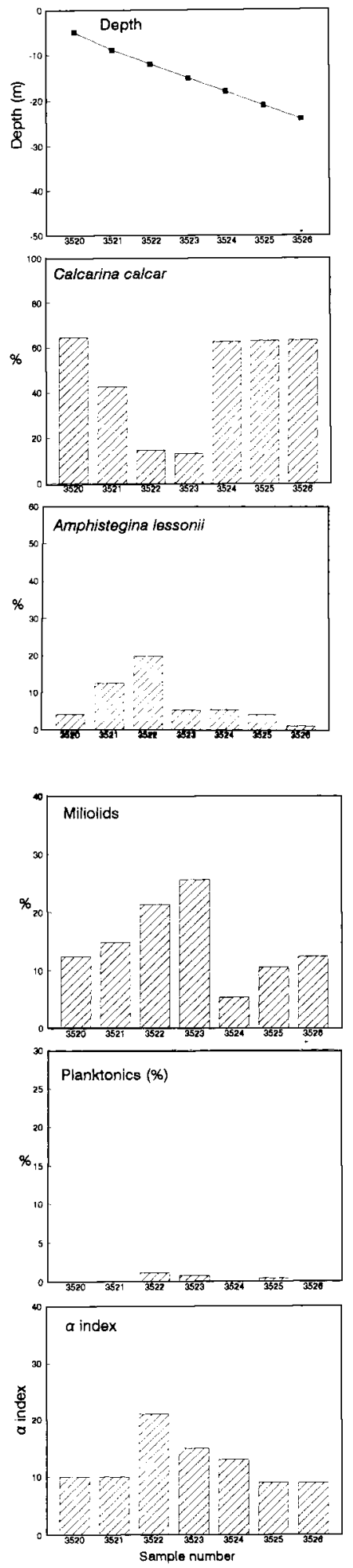

Fig. 4. Frequency distribution of Calcarina calcar, Amphistegina lessonii, miliolids, $\alpha$ index and \% planktonic foraminifera in depth traverses in the lagoon off ile du Coin.
Lagoon
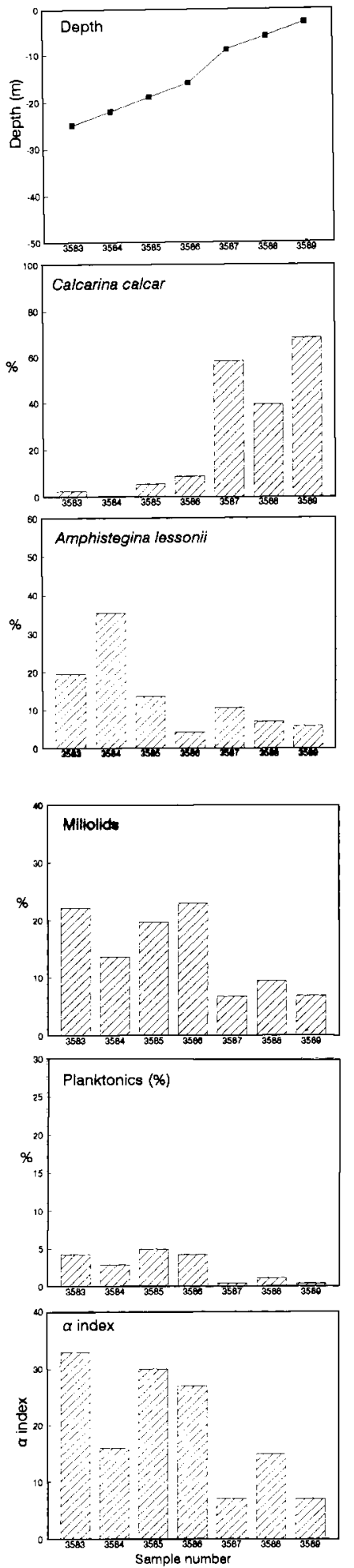

Fig. 5. Frequency distribution of Calcarina calcar, Amphistegina lessonii, miliolids, $\alpha$ index and $\%$ planktonic foraminifera in depth traverses in the lagoon off Petite île Coquillage. 

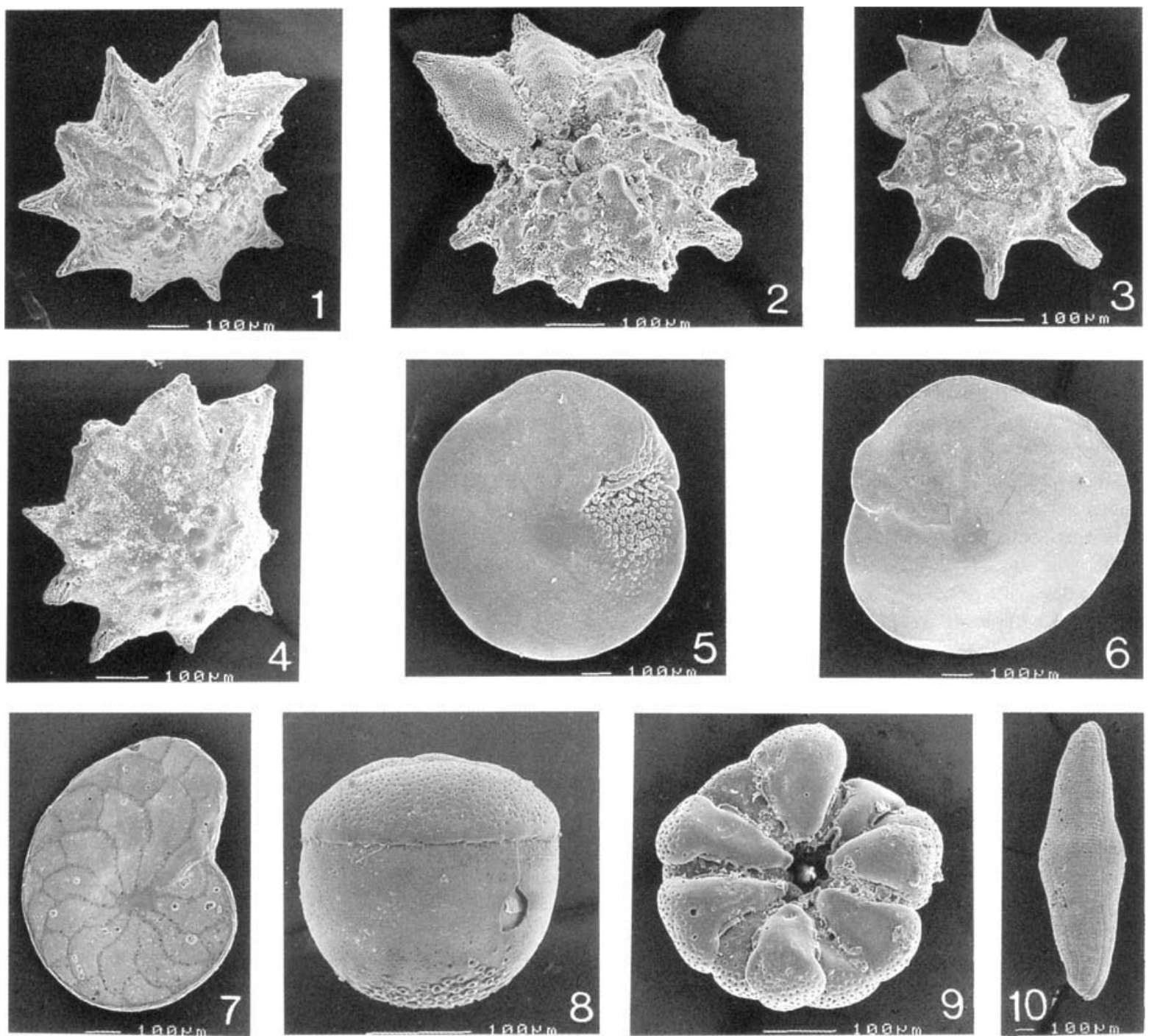

Fig. 6. SEM micrographs: figs 6.1-6.4, Calcarina calcar Deshayes; figs 6.5-6.6, Amphistegina lessonii d'Orbigny; fig. 6.7, Heterostegina depressa d'Orbigny, juvenile individual. fig. 6.8, Tretomphalus sp; fig. 6.9; Cymbaloporetta sp; fig. 6.10, Borelis schlumbergeri (Reichel).

Coquillage, $C$. calcar is abundant on the coarse shallow water sediments but has low abundance $(<9 \%)$ on the fine-grained sediment at $16-25 \mathrm{~m}$. The miliolids are variable as elsewhere and Amphistegina lessonii is generally more abundant on the fine sediment (up to $35 \%$ ). Locally the Cymbaloporetta/ Tretomphalus group reach abundances of $>10 \%$. Planktonic foraminifera are rare throughout the lagoon sediments.

The miliolid group includes Quinqueloculina, Triloculina, Spiroloculina, Miliolinella, and Pyrgo. All other benthic taxa occur in small numbers and no attempt has been made to identify every species. They include planorbulinids, discorbids, rosalinids, cibicidids, bolivinids, eponidids, juvenile nummulitids, soritids, peneroplids and textulariids.

\section{DISCUSSION}

The most obvious contrast between the seaward and lagoon assemblages is in the dominant species: Amphistegina lessonii and Calcarina calcar respectively. Miliolids are more abundant in the lagoon, while planktonic tests are typical of the seaward profiles. The differences in diversity and wall structure group abundance are minor.

The substrates are generally coarse both seaward and in the lagoon: fine sand to granule-sized gravel. The environment is of moderate to high energy due to the combined effects of oceanic swell waves, tidal exchange and persistent winds (Pugh \& Rayner, 1981). Most of the foraminiferal tests show abrasion damage and it is doubtful whether they are preserved exactly where they lived. The 
only fine-grained sediment is in the deeper lagoon off Petite île Coquillage and here the assemblages include many juvenile tests which are well preserved. These samples also have anomalously high species diversity values probably due to the post-mortem concentration of juvenile tests derived in part from adjacent environments.

Calcarina calcar is rare in the Kerimba archipelago (Heron-Allen \& Earland, 1914-15), in the Mascarene Islands (Réunion, Mauritius, Rodriquez; Montaggioni, 1981), and somewhat more abundant in shallow waters in the Comoro Islands (LeCalvez in Guilcher et al., 1965). In the Indian Ocean, only in the îles Glorieuses (Battistini et al., 1976) and the Maldive Islands (0-20 m, Hottinger, 1980), have associations dominated by this species been recorded. In the Pacific Ocean, they are known from Palau (Hallock 1984) and New Caledonia (Lessard 1980, as Tinoporus) in water $0-3 \mathrm{~m}$ deep. In each case, the area is sheltered by a reef barrier.

There is considerable taxonomic confusion surrounding species of the genus Amphistegina (Larsen, 1976). Amphistegina spp. are generally abundant in shallow water carbonate reefal sediments in the Indian and Pacific oceans (Murray, 1991). A. lessonii and A. lobifera are abundant in fore- and back-reef sediments between meadows of brown algae in fairly high energy areas at depths $<30 \mathrm{~m}$ (Montaggioni 1981). LeCalvez (in Guilcher et al., 1965) recorded 8 species in the Comoro Islands and 5 of these (including $A$. lessonii) were abundant. In the Red Sea, $A$. lessonii lives in large numbers between 10 and $20 \mathrm{~m}$, on the lower, shaded surface of boulders or within the coarse sediment. It contains diatom algal symbionts (Fragilaria shiloi Lee) and the habitats are occupied because of their needs (Reiss \& Hottinger, 1984). In this study, A. lessonii is the sole species and it is abundant mainly seaward of the reef.

The abundance of miliolids is variable and does not generally exceed $30 \%$. Similar abundances are known from Réunion and leeward reefs of Mauritius, but the back-reef muddy sediments of windward reefs on Mauritius and on Rodrigues have 60-90\% miliolids (Montaggioni, 1981). Peneroplids are generally rare in the Chagos samples and this is also the case in the Mascarene Islands (Montaggioni 1981).

The suborder Miliolina is generally most abundant in subtropical-tropical shallow water environments, in normal marine or hypersaline waters, and commonly in association with seagrasses or other submarine vegetation (Murray, 1987, 1991). They are particularly abundant in such environments in the Arabian Gulf (see Murray (1991) for references) and in the Gulf of Suez (Azazi, 1992). Their modest abundance in the Chagos sediments may be attributed to the lack of suitable phytal and fine grained sedimentary substrates, which in turn are largely due to the high energy setting.

Alveolinids are rare in the Chagos sediments and their tests are small (Borelis schlumbergeri). With the exception of muddy sediments in the lagoon off Petite île Coquillage, $B$. schlumbergeri is restricted to the seaward side of the reefs. Using published data, Murray (1991, fig. 18.6) summarized the distribution of alveolinids in the world oceans and showed that both Alveolinella and Borelis are present in the western Indian Ocean. Only Borelis is present in the Red Sea as B. schlumbergeri (diatom symbionts) (Hottinger, 1977; Reiss \& Hottinger, 1984).

The remainder of the fauna is similar to that listed from other Indian Ocean reefal areas and includes a number of attached morphotypes such as planorbulinids, cibicidids, rosalinids and discorbids. This is to be expected in such high energy environments.

As total assemblages have been studied, because the samples were inadequately preserved to distinguish living and dead, it is unlikely that they give a completely true picture of the distribution of taxa. Many of the tests are broken and abraded due to the high energy of the environment. It is probable that some transport has taken place with movement of individuals into shallower or deeper water than they occupied during life. Nevertheless, the broad distribution patterns are considered to be valid and the distinctive differences between the seaward and lagoon assemblages are believed to be real.

\section{CONCLUSIONS}

The Peros Banhos atoll is a moderately high energy environment because of the tidal exchange of water between the lagoon and the open sea, the oceanic swell waves and the influence of winds. Submarine vegetation is sparsely present. The samples examined were all from bare sediments, and most are mixtures of fine to coarse sands and gravels made entirely of calcareous bioclasts.

The benthic foraminiferal total assemblages from the seaward side of the reefs are dominated by Amphistegina lessonii while those of the lagoon have a predominance of Calcarina calcar. Miliolids vary in abundance and generally make up $<30 \%$ of the total. In this respect, the Chagos assemblages differ from those of more sheltered carbonate environments with muddy substrates and seagrasses where miliolids commonly constitute $50-90 \%$ of the assemblages. Notwithstanding some post-mortem transport and damage to tests, it is considered that the distribution patterns are broadly representative of the living distributions.

\section{ACKNOWLEDGEMENTS}

We are grateful to Mrs J. Morris for donating the Chagos samples collected by her late husband. Dr C. Sheppard (Newcastle) provided help with literature and kindly read the manuscript. Barbara Cressey and Tim Khan assisted with SEM preparation and Barry Marsh printed the photographs.

\section{Manuscript received May 1993 Manuscript accepted January 1994}

\section{APPENDIX 1: PARTIAL FAUNAL REFERENCE LIST}

The name used in this paper is followed by the original name, author and date.

Amphistegina lessonii d'Orbigny, 1826

Borelis schlumbergeri (Reichel) $=$ Neoalveolina schlum bergeri Reichel, 1937 
Calcarina calcar Deshayes, 1830

Heterostegina depressa d'Orbigny, 1826

\section{REFERENCES}

Azazi, G. 1992. Recent sea floor benthonic foraminifcral analysis from the Gulf of Suez, Egypt. In Takayanagi, Y. \& Saito, T. (Eds), Studies in benthic foraminifera, Procecdings of the fourth international symposium on benthic foraminifera, Sendai, 1990. 135-149, Tokai University Press, Sendai.

Backman. J., Duncan, R. A. et al. 1988. Sites 712 and 713 . Proceedings of the Ocean Drilling Project, Initial Reports, 115, 733-845, College Station, Texas (Ocean Drilling Program).

Battistini, R., Gayet, J., Jouannic, C., Labracherie, M., Peypouquet, J. P., Pujol, C., Pujos-Lamy, A. \& Yuron, J. L. 1976. Etudes des sédiments et de la microfaune des illes Glorieuses (Canal de Mozambique). Cahiers Office de la Recherche Scientifique et Téchnique Outre-Mer, Sćr. Géol, 8: 147-171.

Drew, E. A. 1980. Seagrasses in the Chagos Archipelago. Aquatic Botany, 9: $170-184$.

Duncan, R. A. \& Hargreaves, R. B. 1990. ${ }^{41} \mathrm{Ar} /{ }^{39} \mathrm{Ar}$ geochronology of basement rocks from the Mascarene Plateau, the Chagos Bank, and the Maldives Ridge. In Duncan, R. A, Backman, J., Peterson, L. C. et al. (Eds), Proceedings of the Ocean Drilling Project, Scientific Results, 115: 43-51, College Station. Texas (Ocean Drilling Program).

Fisher, R. A., Corbet, A. S. \& Williams, C. B. 1943. The relationship between the number of species and the number of individuals in a random sample of an animal population. Journal of Animal Ecology, 12: 42-58.

Guilcher, A., Berthois, L., LeCalvez, Y., Battistini, R. \& Crosnier, A. 1965. Les récifs coralliens et le lagon de l'île Mayotte (Archipcl des Comores, Océan Indien). Mémoire Office de la Recherche Scientifique et Téchnique Outre-Mer, 181-201.

Hallock, P. 1984. Distribution of selected species of living algal symbiont-bearing foraminifera on two Pacific coral reefs. Journal of Forarniniferal Research, 14: 250-261.

Heron-Allen, E. \& Earland, A. 1914-1915. The Foraminifera of the Kerimba Archipelago (Portuguese East Africa). Transactions of the Zoological Society of London, 20: 363-390, 543-790.

Hottinger. L. 1977. Distribution of larger Peneroplidae, Borelis and Nummulitidae in the Gulf of Elat, Red Sea. Utrecht Micropalaeontological Bulletin, 15: 35-110.
Hottinger, L. 1980. Repartition comparée des grands foraminifères de la Mer Rouge et de l'Océan Indien. Annali dell'Universita de Ferrara (NS Sez IV), Supplement 6 1-13.

Larsen, A. R. 1976. Studies of recent Amphistegina, laxonomy and some ecological aspects. Israel Journal of Earth Sciences, 25: $1-26$.

Lessard, R. H. 1980. Distribution patterns of intertidal and shallow-water foraminifera of the tropical Pacific Ocean. Cushman Foundation Special Publication, 19: 40-58.

McKenzie, D. P. \& Sclater, J. G. 1971. The evolution of the Indian Ocean since the late Cretaceous. Geophysical Journal of the Royal Astronomical Society, 25: 437-528.

Montaggioni, L. F. 1981. Les associations de foraminiferes dans les sédiments récifaux de l'archipel des Mascarcignes (Océan Indien). Annales de l'Institute Océonographique, Paris, 57: 41-62.

Murray, J. W. 1987. Benthic foraminiferal assemblages: criteria for the distinction of tenmperate and subtropical carbonate environments. In Hart, M. B. (Ed), Micropalaeontology of carbonate environments. 9-20, Ellis Horwood, Chichester.

Murray, J. W. 1991. Ecology and palaeoecology of benthic foraminifera. Longman, Harlow.

Murray, J. W. in press. Larger foraminifera from the Chagos archipelago: their significance for Indian Ocean biogeography. Marine Micropaleontology.

Pugh, D. T. \& Rayner, R. F. 1981. The tidal regimes of three Indian Ocean atolls and some ecological implications. Estuarine Coastal and Shelf Science, 13: 389-407.

Rayner, R. F. \& Drew, E. A. 1984. Nutrient concentrations and primary productivity at the Peros Banhos and Salomon atolls in the Chagos Archipelago. Estuarine Coastal and Shelf Science, 18: $121-132$.

Reiss, Z. \& Hottinger, L. 1984 The Gulf of Aqaba. Ecological micropaleontology. Springer-Verlag, Berlin.

Sheppard, C. R. C. 1980. Coral cover, zonation and diversity on reef slopes of Chagos atolls, and population structures of the major species. Marine Ecology-Progress Series, 2: 193-205.

Sheppard. C. R. C. 1981. The groove and spur structures of Chagos atolls and their coral zonation. Estuarine Coastal and Shelf Science, 12: $549-560$.

Sheppard, C. \& Wells, S. M. 1988. Coral reefs of the world, vol. 2: Indian Ocean, Red Sea and Gulf. United Nations Environmen1 Programme, International Union for Conservation of Nature and Natural Resourses, 37-46. 